\title{
KEEFEKTIFAN PEMBERIAN NEBULIZER TERAPI COMBIVENT DAN TERAPI BISOLVON TERHADAP PATENSI JALAN NAFAS PADA PASIEN ASMA BRONKIAL DIRUANG IGD BBKPM MAKASSAR
}

\author{
Siti Lestari ${ }^{1}$, Siti Handayani ${ }^{2}$, Herman Bakri ${ }^{3}$ \\ ${ }^{1,2}$ Poltekkes Kemenkes Surakarta Jurusan Keperawatan, ${ }^{3}$ BBKPM Makasar \\ Diterima : 26 November 2018 , Disetujui : 3 Desember 2018 \\ e-mail: lestaristi68@gmail.com
}

\begin{abstract}
Background : Asthma is a worldwide health problem. People with asthma in the world today was estimated at 300 million peoples, and expected in 2025 reached 400 million peoples. In Indonesia, there were currently about 12.5 million peoples. In BBKPM Makassar, the number of people with asthma who visit in 2009 were 291 patients, in 2010 to 292 patients, and in 2011 starting from January to November, as 243 patients. It shows the number of people with asthma who visit the BBKPM Makassar each month has increased. Therapy of asthma treatment often used was nebulizer using combivent and bisolvon. Purpose this study to determine the effectiveness of provision nebulizer of combivent and bisolvon therapy to airway patency in asthma bronchial patient at ER of BBKPM Makassar. Method: used was quase experimental with two groups pretest and posttest design. Sample of 40 patients who met the criteria were randomly selected to be divided into two groups, 20 samples for nebulizer of combivent therapy, and 20 samples for nebulizer of bisolvon therapy. Method: Technique of data analysis used was paired $t$ test. the Research result conducted on two groups of respondents, obtained $t$ count value frequency of respiratory and pulmonary physiology in the treatment group of nebulizer using combivent obtained $t$ count of the frequency of respiratory physiology was 15.601 and pulmonary physiology was 23.083, while the treatment groups of nebulizer using bisolvon obtained t count value was 7.701 and pulmonary physiology was 12.606. Result: were both higher than the t table value 1.725 at significant level 95\%. Conclusion: Provision nebulizer of combivent therapy provide greater effectiveness in reducing airway obstruction in asthma bronchial patients at ER of BBKPM Makassar in 2012.
\end{abstract}

Keywords: Nebulizer, Combivent, Bisolvon, Airway Patency, Asthma Bronchial

\section{PENDAHULUAN}

Asma merupakan problem kesehatan diseluruh dunia. Jumlah penderita asma didunia saat ini diperkirakan mencapai 235 juta orang, dan diperkirakan dan 383.000 meninggal dunia karena asma (WHO, 2015). Menurut laporan organisasi kesehatan dunia atau WHO dalam World Health Report 2000 menyebutkan lima penyakit paru utama merupakan $17,4 \%$ penyebab dari seluruh kematian didunia, masingmasing infeksi paru 7,2\%, PPOK 4,8\%, tuberkolosis 3,0\%, kanker paru / trakhea / bronkhus 2,1\%, dan asma $0,3 \%$ (http://www.suara pembaruan.com, 2008). International Study on Asthma and Alergies in Childhood pada tahun 2005 menunjukkan prevalensi gejala asma melonjak dari sebesar 4,2 persen menjadi 
5,4 persen dari seluruh penduduk Indonesia, artinya saat ini ada sekitar 12,5 juta penderita asma di Indonesia (Dewan Asma Indonesia / DAI 2009).

Di Balai Besar Kesehatan Paru Masyarakat (BBKPM) Makassar, jumlah penderita penyakit asma cukup tinggi. Tahun 2009, jumlah pasien asma bronkial yaitu 291 penderita. Tahun 2010 menjadi 292 penderita, dan pada tahun 2011 terhitung dari Januari - November, total penderita asma bronkial sebanyak 243 penderita. Sedangkan jumlah pasien asma yang diberikan tindakan nebulizer diruang Instalasi Gawat Darurat (IGD) BBKPM Makassar terhitung dari bulan September sebanyak 13 orang, Oktober sebanyak 17 orang, dan pada bulan November menjadi 25 orang. Ini menunjukkan jumlah penderita asma yang berkunjung diruang IGD BBKPM Makassar tiap bulannya mengalami peningkatan. Adapun terapi yang paling sering digunakan untuk menangani pasien yang mengalami serangan asma bronkial yaitu menggunakan terapi nebulizer dengan obat yang digunakan adalah Combivent 0,1\% 1 ML (1 MG) yang kandungannya adalah Salbutamol dan Ipatropium Bromide dimana obat ini berfungsi untuk melonggarkan saluran nafas dengan cara merelaksasi bronkus. Akan tetapi, Ipatropium Bromide juga mempunyai efek samping yaitu menyebabkan mulut kering, mengantuk, dan gangguan penglihatan sehingga pemberiannya harus tepat sesuai dengan dosis yang ada. Obat yang juga sering digunakan yaitu Bisolvon 0,2 \% 1 ML (2 MG) yang kandungannya yaitu Bromhexine Hydrocloride yang berfungsi untuk mengencerkan dahak.

Kecenderungan

peningkatan jumlah penderita asma yang cukup tinggi, diperlukan pengobatan yang tepat dan benar agar tidak menyebabkan kematian. Salah satu penatalaksanaan atau terapi farmakologi pada pasien asma bronkial adalah pemberian terapi kortikosteroid dan albuterol dalam bentuk inhalasi atau dengan nebulizer (Widjaya, I, 2010). Berdasarkan penggunaannya maka obat asma terbagi atas dua golongan yaitu pengobatan jangka panjang untuk mengontrol gejala asma, dan pengobatan jangka cepat untuk mengatasi serangan akut asma. Untuk mengatasi serangan akut asma yang paling cepat biasanya menggunakan larutan Nebulizer, MDI (Metered - Dose Inhaler), dan DPI (Dry Power Inhaler) (Ikawati. Z., 2011).

\section{METODE PENELITIAN}

Desain penelitian yang digunakan yaitu Quase experimental two groups pretest and posttest design. Populasi dalam penelitian ini adalah pasien asma bronkial yang ditangani diruang IGD BBKPM Makassar provinsi Sulawesi Selatan. Pengambilan sampel terhadap 40 responden dilakukan dengan tekhnik purposive sampling.

\section{HASIL PENELITIAN}

Responden dalam penelitian ini adalah 40 orang, terdiri laki-laki 18 (45 $\%)$ dan perempuan $22(55 \%)$.

Tabel 1. Karakteristik responden berdasarkan adanya peningkatan frekuensi nafas pasien asma bronkial di ruang IGD BBKPM Makassar

\begin{tabular}{cccc}
\hline No & $\begin{array}{c}\text { Tanda dan Gejala } \\
\text { Peningkatan Frekuensi Frekuensi (f) } \\
\text { Nafas }\end{array}$ & $\begin{array}{c}\text { Persent } \\
\text { ase (\%) }\end{array}$ \\
\hline 1 & Ada & 40 & 100 \\
2 & Tidak Ada & 0 & 0 \\
\hline & Total & 40 & 100 \\
\hline
\end{tabular}


Berdasarkan tabel diatas, terlihat bahwa seluruh responden (100\%) mengalami peningkatan frekuensi nafas selama serangan asma bronkial.

1. Adanya Wheezing

Tabel 2. Karakteristik responden berdasarkan adanya wheezing pada pasien asma bronkial di ruang IGD BBKPM Makassar

\begin{tabular}{cccc}
\hline No & $\begin{array}{c}\text { Tanda dan } \\
\text { Gejala } \\
\text { Wheezing }\end{array}$ & Frekuensi (f) & $\begin{array}{l}\text { Presentase } \\
(\%)\end{array}$ \\
\hline 1 & Ada & 40 & 100 \\
2 & Tidak Ada & 0 & 0 \\
\hline & Total & 40 & 100 \\
\hline
\end{tabular}

Berdasarkan tabel diatas, terlihat bahwa $100 \%$ responden yang menunjukkan adanya wheezing selama seranan asma.

2. Batuk pada Saat Serangan

Tabel 3. Karakteristik responden berdasarkan adanya batuk pada pasien asma bronkial di ruang IGD BBKPM Makassar.

\begin{tabular}{|c|c|c|c|}
\hline No & Batuk & Frekuensi (f) & Persentase $(\%)$ \\
\hline 1 & Ada & 29 & 72,5 \\
\hline \multirow[t]{2}{*}{2} & Tidak Ada & 11 & 27,5 \\
\hline & Total & 40 & 100 \\
\hline $\begin{array}{l}\text { men } \\
\text { yaitu }\end{array}$ & $\begin{array}{r}\text { Berdasal } \\
\text { sebag } \\
\text { lami bat } \\
\text { ebanyak }\end{array}$ & $\begin{array}{l}\text { Kan tabel di } \\
\text { an besar } \\
\text { k saat terj } \\
9 \text { responden }\end{array}$ & $\begin{array}{l}\text { tas, terlihat } \\
\text { responden } \\
\text { di serangan } \\
72,5 \%) \text {. }\end{array}$ \\
\hline
\end{tabular}

\begin{tabular}{cccc} 
& & & \\
& & & \\
\hline 1 & Baru & 20 & 50 \\
2 & Lama & 20 & 50 \\
\hline & Total & 40 & 100 \\
\hline
\end{tabular}

Berdasarkan tabel diatas, terlihat dari 40 orang responden, 20 orang $(50 \%)$ merupakan serangan baru dan 20 responden $(50 \%)$ merupakan asma bronkial yang kambuh.

3. Penggunaan Otot Bantu Pernafasan pada Saat Serangan.

Tabel 4. Karakteristik responden berdasarkan adanya penggunaan otot bantu pernapasan pada pasien asma bronkial di ruang IGD BBKPM Makassar

\begin{tabular}{cccc}
\hline No & $\begin{array}{c}\text { Penggunaan Otot } \\
\text { Bantu }\end{array}$ & $\begin{array}{c}\text { Frekuensi } \\
\text { (f) }\end{array}$ & $\begin{array}{c}\text { Persentase } \\
(\%)\end{array}$ \\
\hline 1 & Ada & 39 & 97,5 \\
2 & Tidak Ada & 1 & 2,5 \\
\hline & Total & 40 & 100 \\
\hline
\end{tabular}

bahwa sebagian besar responden menggunakan otot bantu pernapasan saat mengalami serangan asma yaitu sebanyak 39 responden $(97,5 \%)$.

4. Kriteria Serangan

Tabel 5. Karakteristik responden berdasarkan kriteria serangan pasien asma bronkial di ruang IGD BBKPM Makassar.

\begin{tabular}{cccl}
\hline No & Kriteria & Frekuensi & Persentase \\
& Serangan & $(f)$ & $(\%)$ \\
\hline
\end{tabular}




\section{Riwayat Penyakit Lain}

Tabel 6. Karakteristik responden berdasarkan penyakit lainnya pada pasien asma bronkial di ruang IGD BBKPM Makassar

\begin{tabular}{cccc}
\hline No & Riwayat Penyakit Lain & $\begin{array}{c}\text { Frekuen } \\
\text { si (f) }\end{array}$ & $\begin{array}{c}\text { Persentase } \\
(\%)\end{array}$ \\
\hline 1 & Penyakit Paru Lain & 11 & 27,5 \\
2 & Penyakit Jantung & 2 & 5 \\
3 & Hamil / Menyusui & 2 & 5 \\
4 & Tidak Ada & 25 & 62,5 \\
\hline & Total & 40 & 100 \\
\hline
\end{tabular}

Berdasarkan tabel diatas, sebagian besar responden tidak mengalami penyakit lain selain asma bronkial yaitu sebanyak 25 responden $(62,5 \%)$.

1. Analisa univariat

a. Distribusi Frekuensi Kelompok

Perlakuan dengan Combivent Hasil penelitian, didapatkan skor kelompok perlakuan nebulizer dengan menggunakan combivent sebagai berikut:

1) Frekuensi Nafas

Dari 20 responden yang diberikan perlakuan nebulizer dengan menggunakan combivent, didapatkan penurunan frekuensi nafas terbanyak yaitu 6 dengan 8 responden $(40 \%)$. Penurunan frekuensi nafas tertinggi yaitu 9 dengan 2 responden (10\%), sedangkan yang terendah yaitu 3 dengan 1 responden $(5 \%)$.

2) Skor Faal Paru

Dari 20 responden yang diberikan perlakuan nebulizer dengan menggunakan combivent, didapatkan rata-rata skor faal paru sebelum perlakuan sebesar $67,53 \%$, rata-rata skor faal paru sesudah perlakuan sebesar
$84,35 \%$, dengan rata-rata selisih skor faal paru sebanyak $16,82 \%$.

b. Distribusi Frekuensi Kelompok Perlakuan dengan Bisolvon (Kelompok Kontrol)

Hasil penelitian, didapatkan skor kelompok perlakuan nebulizer dengan menggunakan bisolvon sebagai berikut:

1) Frekuensi Nafas

Dari 20 responden yang diberikan perlakuan nebulizer dengan menggunakan bisolvon, didapatkan penurunan frekuensi nafas terbanyak yaitu 3 dengan 8 responden (40\%). Penurunan frekuensi nafas yang tertinggi yaitu 12 dengan 1 responden (5\%), sedangkan yang terendah 2 dengan 3 responden (15\%).

2) Skor Faal Paru

Dari 20 responden yang diberikan perlakuan nebulizer dengan menggunakan bisolvon, didapatkan rata-rata skor faal paru sebelum perlakuan sebesar $66,71 \%$, rata-rata skor faal paru sesudah perlakuan sebesar $78,82 \%$, dengan rata-rata selisih skor faal paru sebanyak $12,11 \%$.

2. Analisa bivariat

a. Uji Homogenitas

Tabel 7. Hasil uji homogenitas berdasarkan karakteristik pasien asma bronkial di IGD BBKPM Makassar

\begin{tabular}{lcccc}
\hline \multicolumn{1}{c}{ Karakteristik } & $\mathrm{N}$ & $\begin{array}{l}\text { Levene } \\
\text { statistik }\end{array}$ & .sig & simpulan \\
\hline Umur & 40 & .139 & .712 & Homogen \\
Jenis Kelamin & 40 & .192 & .664 & Homogen \\
Batuk & 40 & 31.382 & .000 & Homogen \\
Kriteria serangan & 40 & .395 & .534 & Homogen \\
Riwayat Penyakit & 40 & .052 & .821 & Homogen \\
Jenis Obat & 40 & 2.211 & .121 & Homogen \\
\hline
\end{tabular}


Hasil analisa pada tabel diatas, menunjukkan nilai Lavene Statistik dari masing-masing variabel $>0,05$. Berdasarkan analisa tersebut maka sebaran data dari masing-masing variabel adalah homogen.

b. Uji Normalitas

Uji normalitas untuk mengetahui apakah masing-masing variabel mempunyai sebaran distribusi data yang normal atau tidak (Arikunto, 2007). Uji normalitas yang digunakan dalam penelitian ini adalah Uji Kolmogorov-Smirnov dengan kriteria hasil apabila perhitungan nilai probabilitas $>0,05$, maka data berdistribusi normal. Hasil uji yang didapatkan adalah sebagai berikut :

Berdasarkan tabel diatas dengan signifikansi 95\%, didapatkan bahwa nilai probabilitas dari masing-masing variabel $>0,05$ $(\rho>0,05)$. Artinya sebaran distribusi data pada masing-masing variabel dengan kurva normal tidak signifikan. Kesimpulannya adalah data pada masing-masing variabel mempunyai sebaran distribusi yang normal.

c. Keefektifan penggunaan nebulizer terapi combivent dan terapi bisolvon (kelompok kontrol) terhadap penurunan frekuensi nafas dan peningkatan faal paru $\left(\mathrm{FEV}_{1}\right)$ pada pasien asma bronkial

1) Kelompok perlakuan nebulizer terapi combivent

a) Perbedaan frekuensi nafas

Tabel 8. Skor Frekuensi Nafas

\begin{tabular}{ccccccc}
\hline Test & Mean & $\begin{array}{c}\text { Selisih } \\
\text { Mean }\end{array}$ & Df & $\mathrm{t}_{\text {hitung }}$ & $\mathrm{t}_{\text {tabel }}$ & $\begin{array}{c}\text { Sig }(2 \\
\text { tailed }\end{array}$ \\
\hline $\begin{array}{c}\text { Pre- } \\
\text { test }\end{array}$ & 34,7 & 6 & 20 & 15,601 & 1,7247 & 0,000 \\
$\begin{array}{c}\text { Post- } \\
\text { test }\end{array}$ & 28,7 & 6 & & & & \\
\hline \multicolumn{7}{c}{} \\
\hline
\end{tabular}

statistik $t$ test untuk uji dua pihak, didapatkan nilai $\mathrm{t}$ hitung sebesar15,601 lebih besar dari $t$ tabel 1,7247 dalam tingkat kepercayaan 95\%, dimana $\rho$ value antara skor frekuensi nafas pretest dan posttest adalah 0,000 lebih kecil dari 0,05. Apabila nilai $\mathrm{t}$ hitung lebih besar atau sama dengan nilai $t$ tabel maka kesimpulannya adalah signifikan dan ada keefektifan penggunaan nebulizer. Sehingga kesimpulannya adalah ada perbedaan antara skor frekuensi nafas pretest dan skor frekuensi nafas posttest pada kelompok perlakuan nebulizer dengan menggunakan combivent.

b) Perbedaan faal paru $\left(\mathrm{FEV}_{1}\right)$

Tabel 9. Skor Faal Paru

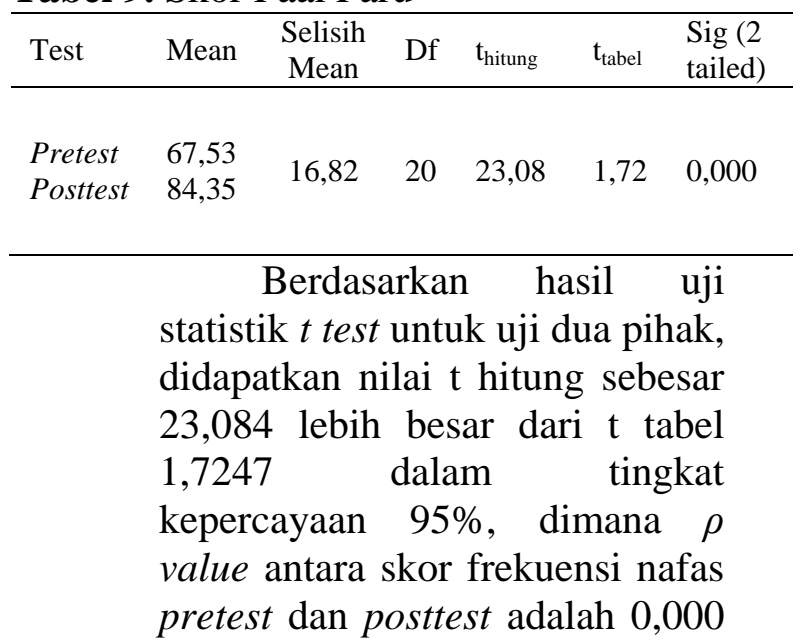


lebih kecil dari 0,05. Apabila nilai $\mathrm{t}$ hitung lebih besar atau sama dengan nilai t tabel maka kesimpulannya adalah signifikan dan ada keefektifan penggunaan nebulizer.

Sehingga

kesimpulannya adalah ada perbedaan antara skor faal paru pretest dan skor faal paru posttest pada kelompok perlakuan nebulizer dengan menggunakan combivent.

2) Kelompok perlakuan nebulizer terapi bisolvon (kelompok kontrol)
a) Perbedaan frekuensi nafas

Tabel 10. Skor Frekuensi Nafas

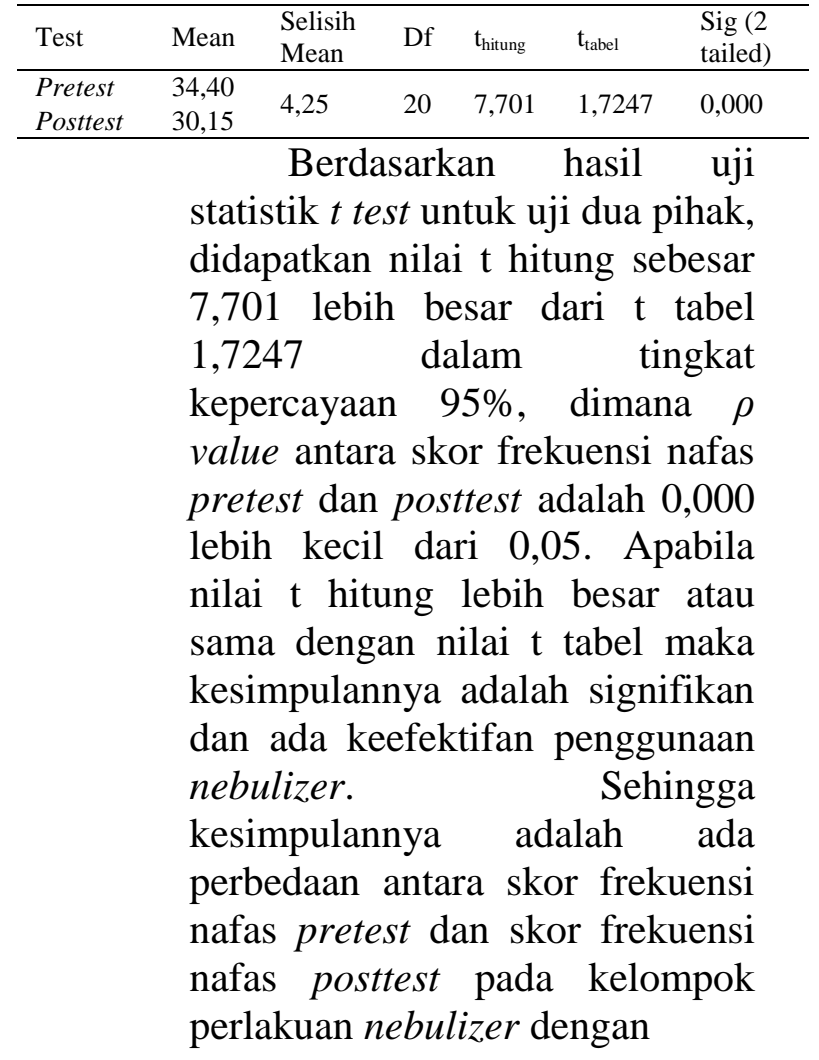

menggunakan bisolvon.

b) Perbedaan faal paru (FEV1)

Tabel 11. Skor Faal Paru

\begin{tabular}{|c|c|c|c|c|c|c|}
\hline Test & Mean & $\begin{array}{l}\text { Selisih } \\
\text { Mean }\end{array}$ & Df & $\mathrm{t}_{\text {hitung }}$ & $\mathrm{t}_{\text {tabel }}$ & $\begin{array}{l}\text { Sig (2 } \\
\text { tailed) }\end{array}$ \\
\hline $\begin{array}{l}\text { Pretest } \\
\text { Posttest } \\
\end{array}$ & $\begin{array}{l}66,71 \\
78,82 \\
\end{array}$ & 12,11 & 20 & 12,60 & 1,72 & 0,000 \\
\hline
\end{tabular}

statistik $t$ test untuk uji dua pihak, didapatkan nilai $t$ hitung sebesar 12,606 lebih besar dari t tabel 1,7247 dalam tingkat kepercayaan 95\%, dimana $\rho$ value antara skor frekuensi nafas pretest dan posttest adalah 0,000 lebih kecil dari 0,05. Apabila nilai $\mathrm{t}$ hitung lebih besar atau sama dengan nilai t tabel maka kesimpulannya adalah signifikan dan ada keefektifan penggunaan nebulizer.

Sehingga

kesimpulannya adalah ada perbedaan antara skor faal paru pretest dan skor faal paru posttest pada kelompok perlakuan nebulizer dengan menggunakan bisolvon.

d. Perbedaan Keefektifan penggunaan nebulizer terapi combivent dan terapi bisolvon (kelompok kontrol) terhadap penurunan frekuensi nafas dan peningkatan faal paru (FEV1) pada pasien asma bronkial

1) Perbedaan keefektifan penggunaan nebulizer terapi combivent dan terapi bisolvon (kelompok kontrol) terhadap frekuensi nafas pada pasien 
asma bronkial

Tabel 12. Perbedaan Efektifitas Penggunaan Combivent dan Bisolvon terhadap Penurunan Frekuensi Nafas

\begin{tabular}{lllllll}
\hline Test & Mean & $\begin{array}{l}\text { Selisih } \\
\text { Mean }\end{array}$ & Df & $\mathrm{t}_{\text {hitung }}$ & $\mathrm{t}_{\text {tabel }}$ & $\begin{array}{l}\operatorname{Sig}(2 \\
\text { tailed })\end{array}$ \\
\hline $\begin{array}{l}\text { Combivent } \\
\text { Bisolvon }\end{array}$ & 6,25 & 1,75 & 40 & $\begin{array}{l}2,86 \\
5\end{array}$ & 1,68 & 0,010 \\
\hline
\end{tabular}

Berdasarkan hasil uji

statistik $t$ test untuk uji dua pihak, didapatkan nilai t hitung sebesar 2,865 lebih besar dari t tabel 1,6838 dalam tingkat kepercayaan $95 \%$, dimana $\rho$ value antara skor frekuensi nafas pretest dan posttest adalah 0,010 lebih kecil dari 0,05. Apabila nilai $\mathrm{t}$ hitung lebih besar atau sama dengan nilai $t$ tabel maka kesimpulannya adalah signifikan dan ada keefektifan penggunaan nebulizer. Sehingga

kesimpulannya adalah ada perbedaan antara penurunan frekuensi nafas antara kelompok perlakuan nebulizer dengan menggunakan combivent dan kelompok perlakuan nebulizer dengan menggunakan bisolvon.

2) Perbedaan keefektifan penggunaan nebulizer terapi combivent dan terapi bisolvon (kelompok kontrol) terhadap faal paru (FEV1) pada pasien asma bronkial

Tabel 12. Perbedaan Efektifitas Penggunaan Combivent dan Bisolvon terhadap Peningkatan Faal Paru

\begin{tabular}{lllllll}
\hline Test & Mean & $\begin{array}{l}\text { Selisih } \\
\text { Mean }\end{array}$ & Df & $\mathrm{t}_{\text {hitung }}$ & $\mathrm{t}_{\text {tabel }}$ & $\begin{array}{l}\text { Sig }(2 \\
\text { tailed })\end{array}$ \\
\hline $\begin{array}{l}\text { Combivent } \\
\text { Bisolvon }\end{array}$ & 16,82 & 4,71 & 40 & 5,220 & $\begin{array}{l}1,683 \\
8\end{array}$ & 0,000 \\
\hline
\end{tabular}

Berdasarkan hasil uji statistik $t$ test untuk uji dua pihak, didapatkan nilai t hitung sebesar 5,220 lebih besar dari t tabel 1,6838 dalam tingkat kepercayaan 95\%, dimana $\rho$ value antara skor frekuensi nafas pretest dan posttest adalah 0,000 lebih kecil dari 0,05. Apabila nilai $\mathrm{t}$ hitung lebih besar atau sama dengan nilai $\mathrm{t}$ tabel maka kesimpulannya adalah signifikan dan ada keefektifan penggunaan nebulizer. Sehingga kesimpulannya adalah ada perbedaan antara peningkatan faal paru antara kelompok perlakuan nebulizer dengan menggunakan combivent dan kelompok perlakuan nebulizer dengan menggunakan bisolvon.

e. Penggunaan nebulizer yang memberikan keefektifan lebih besar antara penggunaan nebulizer terapi combivent dan terapi bisolvon terhadap peningkatan patensi jalan nafas pada pasien asma bronkial.

Tabel 13. Perbandingan antara $\mathrm{t}$ hitung Kelompok Perlakuan Nebulizer dengan Combivent dan Nebulizer dengan Bisolvon

\begin{tabular}{|c|c|c|}
\hline \multirow{2}{*}{ Perlakuan } & \multicolumn{2}{|c|}{$t_{\text {hitung }}$} \\
\hline & Frekuensi Nafas & Faal Paru \\
\hline Combivent & 15,601 & 23,083 \\
\hline Bisolvon & 7,701 & 12,606 \\
\hline
\end{tabular}
kelompok perlakuan di atas, didapatkan nilai $\mathrm{t}$ hitung frekuensi nafas dan faal paru pada kelompok perlakuan nebulizer dengan menggunakan combivent lebih besar dari kelompok perlakuan nebulizer dengan menggunakan bisolvon 
$(15,601>\quad 7,701 / 23,083>12,606)$.

Kesimpulannya adalah pemberian nebulizer terapi combivent dan terapi bisolvon efektif tehadap patensi jalan nafas pada pasien asma bronkial

\section{PEMBAHASAN}

1. Karakteristik penderita asma bronkial di IGD BBKPM Makassar

a. Kelompok umur

Berdasarkan penelitian yang telah dilakukan pada 40 responden, maka didapatkan jumlah penderita asma bronkial terbanyak adalah responden berusia 41 - 45 tahun dan 46 - 50 tahun berjumlah 7 orang $(17,5 \%)$. Ini menunjukkan bahwa asma lebih banyak ditemukan pada usia dewasa. Separuh dari semua kasus asma berkembang sejak masa kanak-kanak, sepertiganya pada masa dewasa umur 40 tahun. Ini terjadi karena pada anak-anak lebih mudah terpapar allergen. Sedangkan masa usia dewasa, serangan asma pada umumnya terjadi karena faktor lingkungan, seperti asap rokok, polusi udara, stress, lingkungan kerja maupun karena olahraga. Namun demikian, asma dapat dimulai dari segala usia, mempengaruhi pria dan wanita tanpa kecuali, dan bisa terjadi pada setiap orang pada segala etnis (Ikawati, 2011).

b. Jenis kelamin

Berdasarkan penelitian yang telah dilakukan pada 40 responden, maka didapatkan bahwa responden berjenis kelamin perempuan sebanyak 22 responden $(55 \%)$. Jenis kelamin merupakan faktor resiko dari serangan asma, dimana jenis kelamin pria merupakan faktor resiko asma pada anak-anak. Pada anak dibawah usia 14 tahun, prevalensi asma pada anak laki-laki hampir dua kali lipat dari anak perempuan. Namun demikian, pada usia dewasa kejadian asma lebih bnyak pada wanita daripada pada pria. Belum diketahui penyebab perbedaan akibat jenis kelamin ini. Diduga, ini terjadi karena ukuran paru/ saluran nafas pada pria lebih kecil daripada wanita saat kanakkanak, tetapi menjadi lebih besar pada usia dewasa (Ikawati, 2011).

c. Peningkatan frekuensi nafas

Berdasarkan penelitian yang telah dilakukan pada 40 responden, maka terlihat bahwa responden yang mengalami peningkatan frekuensi nafas selama serangan asma bronkial sebanyak 40 responden (100\%). Ini sesuai dengan Saryono (2009) bahwa pada asma, diameter bronchiolus akan berkurang selama ekspirasi dari pada selama inspirasi. Ini terjadi karena adanya peningkatan tekanan dalam paru selama ekspirasi paksa menekan bagian luar bronchiolus. Karena bronchiolus sudah tersumbat sebagian, maka sumbatan selanjutnya adalah akibat dari eksternal yang menimbulkan obstruksi berat terutama selama ekspirasi. Pada penderita asma biasanya akan dapat melakukan ekspirasi dengan baik dan adekuat, tetapi sekali-kali melakukan ekspirasi. Hal ini akan menyebabkan terjadinya dispnea. Kapasitas residu fungsional dan volume residu paru 
menjadi sangat meningkat selama serangan asma akibat kesulitan mengeluarkan udara ekspirasi dari paru. Rahmawati (2009), dampak adanya hambatan pada jalan nafas akan menimbulkan dampak pada sistem-sistem tubuh yaitu adanya peningkatan frekuensi nafas, susah bernafas, periode inspirasi agak pendek dan periode ekspirasi yang panjang.

d. Adanya wheezing

Berdasarkan penelitian yang telah dilakukan pada 40 responden, maka terlihat bahwa responden yang menunjukkan adanya wheezing sebanyak 40 responden (100\%). Hal ini sesuai dengan Soemantri (2009), bahwa mengi merupakan gejala khas dan harus ada. Ini disebabkan karena terjadinya edema mukosa dan pembengkakan bronkus yang semakin menambah menyempitnya saluran nafas sehingga akan terasa sesak, berusaha untuk bernafas dalam, dan ekspirasi yang memanjang (Barbara C.L, 2000). Pada keadaan serangan asma, kontraksi otot polos saluran nafas, edema, dan hipersekresi dapat menyumbat saluran nafas. Maka sebagai kompensasi penderita bernafas pada volume paru yang lebih besar untuk mengatasi menutupnya saluran pernafasan. Hal itu meningkatkan kerja pernafasan. Hiperresponsivitas saluran nafas dan menimbulkan tanda klinis berupa sesak nafas, mengi dan hiperinflasi (Ikawati, 2011).

e. Batuk pada saat serangan

Berdasarkan penelitian yang telah dilakukan pada 40 responden, sebagian besar responden mengalami batuk saat terjadi serangan yaitu sebanyak 29 responden $(72,5 \%)$. Ini terjadi karena adanya penyumbatan saluran nafas oleh mukus yang disebabkan karena terjadinya perubahan tingkat hiperplasia kalenjer submukosa pada saluran nafas (Soemantri, 2009). Kementrian Kesehatan (2017) dan Black dan Hawks, 2014, serangan asma ditandai dengan adanya batukbatuk berkala yang terjadi karena iritasi mukosa yang kental dan mengumpul. Ini ditandai dengan batuk disertai mukus yang jernih dan berbusa.

f. Penggunaan otot bantu pernafasan

Berdasarkan penelitian yang telah dilakukan pada 40 responden, sebagian besar responden menggunakan otot bantu pernapasan saat mengalami serangan asma yaitu sebanyak 39 responden (97,5\%). Ini dijelaskan Rahmawati (2009), Pada penderita asma terjadi peningkatan pemendekan otot polos bronkus saat isotonik. Perubahan fungsi kontraksi mungkin disebabkan oleh perubahan aparatus kontraksi.

g. Kriteria serangan

Berdasarkan penelitian yang telah dilakukan pada 40 responden, 20 responden $(50 \%)$ merupakan serangan baru dan 20 responden (50\%) merupakan asma bronkial yang kambuh. Ini sesuai dengan Ikawati (2011), bahwa serangan asma bronkial terjadi karena dua faktor. Yang pertama faktor ekstrinsik yaitu disebabkan karena menghirup allergen yang biasanya terjadi pada anak-anak yang memiliki keluarga dengan riwayat penyakit alergi. Tipe ini yang akan 
kambuh tiap kali terpapar oleh alergen. Sedangkan yang kedua adalah faktor ekstrinsik yaitu mengacu pada faktor diluar mekanisme imunitas dan umumnya dijumpai pada usia dewasa. Faktor ini meliputi stress, olahraga, aktifitas yang berat serta obatobatan.

h. Riwayat penyakit lain

Berdasarkan penelitian yang telah dilakukan pada 40 responden, sebagian besar responden tidak mengalami penyakit lain selain asma bronkial yaitu sebanyak 25 responden (62,5\%). Ini sesuai dengan Ikawati (2011), sebagian besar penderita asma disebabkan oleh adanya riwayat alergi, yaitu $80 \%$.

2. Analisa univariat

Untuk mengetahui keefektifan penggunaan nebulizer terapi combivent dan terapi bisolvon (kelompok kontrol) terhadap penurunan frekuensi nafas dan peningkatan faal paru $\left(\mathrm{FEV}_{1}\right)$ pada pasien asma bronkial

Berdasarkan hasil analisa data mengenai keefektifan penggunaan nebulizer terhadap penurunan frekuensi nafas dan peningkatan faal paru $\left(\mathrm{FEV}_{1}\right)$ pada dua kelompok responden pasien asma bronkial, yaitu kelompok perlakuan nebulizer terapi combivent dan kelompok perlakuan nebulizer terapi bisolvon (kelompok kontrol), didapatkan bahwa signifikan atau ada perbedaan skor frekuensi nafas dan perbedaan skor peningkatan nilai faal paru $\left(\mathrm{FEV}_{1}\right)$ antara skor pretest dan skor posttest pada kedua kelompok.
Hal ini sesuai dengan yang dikemukakan Khairiyaf, O.C \& Yusrizal, F. (2002) dalam penelitiannya, bahwa pengobatan pasien asma bronkial lebih efektif menggunakan nebulisasi dari pada menggunakan terbutalin sub kutan.

Didukung dengan teori bahwa pemberian nebulizer pada pasien asma bronkial menimbulkan medikasi langsung pada tempat / sasaran aksinya (seperti paru), pengiriman obat ke paru sangat cepat, sehingga aksinya lebih cepat daripada rute lainnya seperti subkutan atau oral, serta dosis yang rendah dapat menurunkan absorbsi sistemik dan efek samping sistemik (Ikawati, 2011).

3. Analisa bivariat

Berdasarkan hasil analisa data mengenai perbedaan keefektifan penggunaan nebulizer terapi combivent dan terapi bisolvon (kelompok kontrol) terhadap penurunan frekuensi nafas dan peningkatan faal paru $\left(\mathrm{FEV}_{1}\right)$ pada pasien asma bronkial didapatkan signifikan atau ada perbedaan penurunan frekuensi nafas dan peningkatan faal paru $\left(\mathrm{FEV}_{1}\right)$ antara kelompok perlakuan nebulizer terapi combivent dan terapi bisolvon (kelompok kontrol). Dan didapatkan data:

a. Penurunan frekuensi nafas lebih besar terjadi pada kelompok perlakuan nebulizer terapi combivent, yaitu dengan penurunan rata-rata skor sebesar 15,601 sedangkan pada kelompok perlakuan nebulizer terapi bisolvon didapatkan dengan penurunan ratarata skor 7,701 
b. Peningkatan faal paru $\left(\mathrm{FEV}_{1}\right)$ lebih besar terjadi pada kelompok perlakuan nebulizer terapi combivent, yaitu dengan peningkatan rata-rata skor sebesar $23,083 \%$ sedangkan pada kelompok perlakuan nebulizer terapi bisolvon didapatkan dengan peningkatan rata-rata $12,606 \%$

Hal ini sesuai dengan teori bahwa penambahan ipratropium bromida umumnya menghasilkan perbaikan pada fungsi paru 10-15\% lebih tinggi dibandingkan hanya menggunakan agonis $\beta$-2 adrenergik saja. Kombinasi agonis $\beta 2$ adrenergik dan anti kolinergik bekerja dengan mengaktifasi adenilet siklase sehingga meningkatkan kadar siklik AMP intrasel dan merelaksasi otot polos bronkus sehingga melonggarkan jalan nafas pada serangan asma (Ikawati, 2011).

\section{KESIMPULAN DAN SARAN}

Penggunaan nebulizer yang memberikan keefektifan lebih besar antara penggunaan nebulizer terapi combivent dan terapi bisolvon terhadap peningkatan patensi jalan nafas pada pasien asma bronkial

Berdasarkan hasil analisa data mengenai penggunaan nebulizer yang memberikan keefektifan lebih besar terhadap frekuensi nafas dan peningkatan faal paru $\left(\mathrm{FEV}_{1}\right)$ pada pasien asma bronkial didapatkan bahwa kelompok perlakuan nebulizer terapi combivent memberikan efektifitas yang lebih besar dalam menurunkan obstruksi jalan nafas (frekuensi nafas dan faal paru / $\mathrm{FEV}_{1}$ ) pada pasien asma bronkial.

Hasil ini sesuai dengan teori bahwa penambahan ipratropium bromida umumnya akan menghasilkan perbaikan pada fungsi paru $10-15 \%$ lebih tinggi dibandingkan hanya menggunakan agonis $\beta$-2 adrenergik saja. Kombinasi agonis $\beta 2$ adrenergik dan anti kolinergik bekerja dengan mengaktifasi adenilet siklase sehingga meningkatkan kadar siklik AMP intrasel dan merelaksasi otot polos bronkus sehingga melonggarkan jalan nafas pada serangan asma (Ikawati, 2011).

\section{DAFTAR RUJUKAN}

Barbara, C. (2000). Perawatan Medikal Bedah. Bandung : Yayasan IAPK Padjajaran. Hidayat, A.A.A (2007). Metode Penelitian Keperawatan dan Teknik Analisa Data . Jakarta : Salemba Medika

Black, Joyce $M$ dan Hawks, Jane Hokakson (2014). Medical Surgical Nursing: Clinical Management for positive outcomes, eight edition. USA Saunders : Elsevier

Ikawati, Z. (2011). Penyakit Sistem Pernafasan dan Tata Laksana Terapinya. Yogyakarta : Bursa Ilmu

Ikawati, Z. (2011). Uji Funsi Paru-Paru Tersedia di http://zuliesikawati.staff.ugm.ac.id, retrieved 12 Januari 2012

Kartikawati, D. (2011). Buku Ajar Keperawatan Gawat Darurat. Jakarta : Salemba Medika

Khairiyaf, O.C \& Yusrizal, F. (2002). Perbandinan Efek Terbutalin Subkutan dengan Nebulisasi pada Asma di Unit IGD RSUP Dr Muh Jamil Padang "Tersedia di http://www.webcache.googleuserco ntent.com. Retrieved 19 Desember 2011.

Kementerian kesehatan Republik Indonesia (2017). http://p2ptm.kemkes.go.id/kegiatan- 
p2ptm/subdit-penyakit-paru-kronikdan-gangguan-imunologi/asmabronkial-faq

Saryono. (2009). Biokimia Respirasi. Yogyakarta: Nuha Medika

Setyawan, B. (2011). Kefektifan Penggunaan Nebulizer selama 20 Menit terhadap Penurunan Obstruksi Jalan Nafas pada Pasien Asma Bronchiale di Ruan IGD RSD Mardi Waluyo Kota Blitar". Skripsi pada Program D-IV Keperawatan Gawat Darurat, Poltekkes Surakarta (Tidak Dipublikasikan).

Sibuaahe, W.H; Panggabean, M.M. \& Gultom, S.P. (2005). Ilmu Penyakit Dalam. Jakarta: Rineka Cipta.

Sumantri, I. (2009). Asuhan Keperawatan Pasien dengan Ganguan Sistem Pernafasan. Jakarta: Salemba Medika.

Wijaya, I. (2010). Buku Pintar Atasi Asma . Yogyakarta: Pinang Merah

WHO, (2015) https://www.who.int/newsroom/fact-sheets/detail/asthm 
